\title{
PENGARUH STRATEGI PEMASARAN TABUNGAN BRI BRITAMA TERHADAP KEPUASAN NASABAH PADA PT. BANK RAKYAT INDONESIA (Persero), Tbk. UNIT BATUA RAYA MAKASSAR
}

\author{
Oleh \\ Dwi Indahsari \\ Institut Bisnis dan Keuangan Nitro Makassar \\ Email : dwiindahsari234@gmail.com
}

\begin{abstract}
The purpose of this study is to determine and analyze the influence of the product on customer satisfaction at PT Bank Rakyat Indonesia (Persero), Tbk.

The type of research used in this research is quantitative research. The analytical tool used is multiple linear regression analysis with the help of SPSS version 18.

Abstrak

Tujuan dari penelitian ini yaitu untuk mengetahui dan menganalisis pengaruh Product terhadap kepuasan nasabah pada PT Bank Rakyat Indonesia (Persero), Tbk.

Adapun jenis penelitian yang digunakan dalam penelitian ini adalah penelitian kuantitatif. Alat analisis yang digunakan adalah analisis regresi linear berganda dengan bantuan SPSS versi 18.
\end{abstract}

Kata Kunci: Product dan Kepuasan Nasabah 


\section{PENDAHULUAN}

\section{A. LATAR BELAKANG}

Pertumbuhan dunia perbankan dewasa ini semakin berkembang di Indonesia. Hal ini ditandai dengan banyaknya bank-bank swasta, baik bank konvensional maupun bank syariah, keduanya saling berkaitan untuk merebut hati nasabah. Penggunaan bank pada masa sekarang sudah menjadi perilaku yang wajib bagi masyarakat pada umumnya, apalagi masyarakat dilingkup perkotaan. Perilaku ini juga didukung dengan kemajuan teknologi dimana fungsi bank yang bukan saja untuk menyimpan uang, tetapi juga dapat digunakan untuk mentransfer uang dan meminjam dana.

Selain itu, proses globalisasi ekonomi juga telah memberikan pengaruh terhadap pertumbuhan dan perkembangan industri perbankan di Indonesia. Perkembangannya ditandai dengan semakin banyaknya bank dengan berbagai macam produk pelayanan yang ditawarkan kepada nasabahnya. Kondisi ini membuat adanya persaingan yang semakin ketat. Sudah menjadi kewajiban perbankan untuk mendapatkan keunggulan bersaing sehingga dapat memenangkan persaingan tersebut.

Pentingnya pemasaran dilakukan dalam rangka memenuhi kebutuhan dan keinginan masyarakat akan suatu produk atau jasa sehingga mencapai kepuasan. Kepuasan tersebut diperoleh jika produk yang dibeli konsumen atau 
nasabah terpenuhi, sedangkan perusahaan dapat memperoleh keuntungan dari penjualan produk yang dihasilkannya. Oleh karena itu, produsen dalam kegiatan pemasaran produk atau jasanya maka diperlukan suatu alat, salah satunya yaitu stategi pemasaran (Rosdiana,2011).

Persaingan perbankan dan situasi bisnis saat ini mengalami perubahan yang sangat cepat. Setiap bank berlomba-lomba untuk menarik nasabah dengan berbagai macam cara dan strategi yang dilakukan. Mulai dari memperkenalkan produk - produk perbankan yang efisien dan paling menguntungkan sampai dengan program pelayanan prima yang ditujukan untuk kepuasan nasabah yang menggunakan jasa bank tersebut.

Kepuasan nasabah dalam bidang jasa merupakan elemen penting dan menentukan dalam mengembangkan perusahaan agar tetap eksis dalam menghadapi persaingan. Demikian pula dengan bisnis perbankan, merupakan bisnis berdasarkan pada asas kepercayaan, sehingga lembaga keuangan harus bisa menciptakan produk yang benar-benar berkualitas dan mampu bersaing dengan perusahaan yang lain. Oleh karena itu, bank perlu mencari strategi pemasaran yang efektif dan berkesinambungan untuk jangka panjang. Pemasaran harus dikelola secara profesional, sehingga kebutuhan dan keinginan nasabah bisa terpenuhi dan terpuaskan.

Kualitas pelayanan tentunya menciptakan kepuasan nasabah terhadap pengguna layanan yang pada akhirnya dapat memberikan beberapa manfaat, diantaranya terjadi hubungan harmonis antara penyedia barang dan jasa dengan 
nasabah. Peningkatan kualitas pelayanan perlu dilakukan secara terus-menerus dalam rangka menjaga kepuasan nasabah. Inovasi-inovasi pelayanan perlu dilakukan sesuai dengan masukan-masukan dari nasabah dan dengan kemampuan unit pelayanan dalam memenuhi keinginan nasabah tersebut. Oleh karena itu, upaya untuk meningkatakan kualitas pelayanan tidak lepas dari upaya untuk mengukur kepuasan pelanggan, yang hasilnya merupakan bahan masukan bagi perbaikan kualitas pelayanan yang diberikan perusahaan terhadap nasabah. Suatu pelayanan akan memiliki kualitas yang baik apabila pelayanan tersebut mampu memenuhi harapan nasabah.

Kunci utama untuk memenangkan persaingan adalah memberikan kepuasan kepada nasabah. Alasannya karena dengan kepuasan nasabah akan berdampak positif pada kinerja perusahaan dan dapat mempertahankan kelangsungan hidup perusahaan. Hal ini menjadi alasan utama bagi setiap perusahaan untuk menarik dan mempertahankan konsumennya.

Dalam kondisi persaingan yang ketat PT. Bank Rakyat Indonesia harus berupaya mengantisipasi perubahan yang terjadi, baik perubahan kebutuhan dan kepentingan nasabah, juga perubahan yang terjadi pada lingkungan.PT. Bank Rakyat Indonesia harus selalu memantau dan mempertahankan hal-hal yang menjadi kebutuhan, kepentingan dan keinginan nasabah. Hal ini merupakan salah satu faktor yang menentukan kepuasan nasabah yang pada akhirnya akan meningkatkan loyalitas nasabah terhadap PT. Bank Rakyat Indonesia. 
Berdasarkan penelitian yang dilakukan oleh Putra dan Sulistyawati (2013), menyatakan bahwa terdapat pengaruh yang signifikan dari bauran pemasaran jasa yang terdiri dari product, price, palce, promotion, people, physical evidence, dan process, secara simultan dan parsial terhadap kepuasan nasabah.

Sedangkan penelitian yang dilakukan oleh Fida Fatimah (2013), menyimpulkan bahwa secara parsial dan secara simultan variabel product tidak berpengaruh secara signifikan terhadap kepuasan nasabah.

Berdasarkan latar belakang diatas, peneliti tertarik untuk melakukan penelitian lebih lanjut mengenai permasalahan tersebut dengan mengambil judul "PENGARUH STRATEGI PEMASARAN TABUNGAN BRI BRITAMA TERHADAP KEPUASAN NASABAH PADA PT. BANK RAKYAT INDONESIA (PERSERO), TBK. UNIT BATUA RAYA MAKASSAR".

TINJAUAN PUSTAKA

A. LANDASAN TEORI

1. Strategi Pemasaran

a. Pengertian Strategi Pemasaran

Menurut Kotler dalam sunyoto (2012:18) mengemukakan bahwa : "Pemasaran adalah suatu proses sosial dan manajerial yang didalamnya individu dan kelompok mendapatkan apa yang mereka butuhkan dan 
inginkan dengan menciptakan, menawarkan dan mempertukarkan produk yang bernilai dengan pihak lain".

Menurut Farida (2012:3) Strategi pemasaran pada umumnya mempunyai peranan yang sangat penting untuk menghadapi lingkungan yang dinamis dan pada akhirnya memperoleh keunggulan tertentu. Strategi pemasaran yang diterapkan harus ditinjau dan dikembangkan sesuai dengan perkembangan pasar dan lingkungan pasar tersebut. Dengan demikian strategi pemasaran harus mendapatkan gambaran yang jelas dan terarah apa yang akan dilakukan perusahaan dalam menggunakan setiap kesempatan atau peluang pada beberapa pasar sasaran.

Menurut assauri (2008) menyimpulkan bahwa strategi pemasaran adalah serangkaian tujuan dan sasaran, kebijakan dan aturan yang memberi arah kepada usaha-usaha pemasaran perusahaan dari waktu ke waktu, pada masing-masing tingkatan dan acuan serta alokasinya, terutama sebagai tanggapan perusahaan dalam menghadapi lingkungan dan keadaan persaingan yang selalu berubah.

\section{b. Konsep Pemasaran}

Menurut kasmir (2004:172-173) dalam kegiatan pemasaran terdapat beberapa konsep yang mana masing-masing konsep memliki tujuan yang berbeda. Saat ini 5 konsep dalam pemasaran dimana masing-masing konsep saling bersaing satu sama lain. Setiap konsep 
dijadikan landasan pemasaran oleh masing-masing perusahaan untuk menjalankan kegiatan pemasarannya. Adapun konsep-konsep pemasaran antara lain:

1. Konsep produksi, yaitu konsep yang menentukan kepada volume produksi yang seluas-luasnya dengan harga yang serendah mungkin.

2. Konsep produk, merupakan konsep yang menekankan kepada kualitas, penampilan dan ciri-ciri yang terbaik.

3. Konsep penjualan, dalam konsep ini kegiatan pemasaran ditekankan lebih agresif melalui usaha-usaha promosi yang gencar.

4. Konsep pemasaran, menentukan kebutuhan, keinginan dan minat pasar sasaran dan memberikan kepuasan yang diinginkan secara lebih efektif dan efisien dari yang dilakukan oleh pesaing.

5. Konsep pemasaran kemasyarakatan, konsep ini menekankan kepada penentuan kebutuhan, keinginan, dan minat pasar serta memberikan kepuasan, sehingga memberikan kesejahteraan nasabah dan masyarakat.

Bagi dunia perbankan konsep yang paling tepat untuk diaplikasikan adalah konsep pemasaran yang bersifat kemasyarakatan atau paling tidak menggunakan konsep pemasaran. Dalam konsep pemasaran tersebut tertian bahwa konsumen adalah segalanya. Kebutuhan, keinginan dan 
kepuasan nasabah benar-benar harus diperhatikan tujuannya adalah agar nasabah tetap setia menggunakan produk-produk atau jasa-jasa yang dihasilkan oleh bank.

\section{c. Fungsi Strategi Pemasaran}

1) Sebagai respon organisasi untuk menanggapi dan menyesuaikan diri terhadap hubungan lingkungan sepanjang siklus bisnis

2) Sebagai upaya untuk membedakan dirinya dari pesaing dengan menggunakan kekuatan korporat untuk memenuhi kebutuhan pelanggan yang lebih baik dalam lingkungan tertentu.

3) Sebagai kunci keberhasilan dalam menghadapi perubahan lingkungan bisnis, memberikan kesatuan arah bagi semua mitra internal perusahaan. Strategi pemasaran yang jelas akan memberikan arah mengombinasikan variabel-variabel segmentasi pasar, identifikasi pasar sasaran, positioning, elemen bauran pemasaran, dan biaya bauran pemasaran konsep strategi yang tidak jelas, keputusan yang diambil akan subyektif.

4) Sebagai pedoman dalam mengalokasikan sumber daya dan usaha organisasi.

d. Bauran Pemasaran

Bauran pemasaran adalah kombinasi variabel atau kegiatan yang merupakan inti dari system pemasaran, variabel mana dapat dikendalikan 
oleh perusahaan untuk mempengaruhi reaksi para pembeli atau konsumen. Jadi bauran pemasaran terdisi dari himpunan variabel yang dapat dikendalikan dan digunakan oleh perusahaan untuk mempengaruhi tanggapan konsumen dalam pasar sasarannya.Variabel atau kegiatan tersebut perlu dikombinasikan dan dikoordinasikan oleh perusahaan seefektif mungkin dalam melakukan tugas atau kegiatan pemasarannya. Dengan demikian, perusahaan tidak hanya sekedar memiliki kombinasi kegiatan yang terbaik saja, akan tetapi dapat mengkoordinasikan berbagai variabel bauran pemasaran tersebut untuk melaksanakan program pemasaran secara efektf. (Tjiptono,2005:30).

\section{Kepuasan Nasabah}

\section{a. Pengertian Kepuasan Nasabah}

Menurut Kotler dan Keller (2012:70) secara umum kepuasan adalah perasaan senang atau kecewa seseorang yang muncul setelah membandingkan antara kinerja (hasil) produk yang dipikirkan pada kinerja yang diharapkan.

Menurut Daryanto (2014:90) kepuasan nasabah adalah keadaan yang dicapai bila produk sesuai dengan kebutuhan atau harapan konsumen dan bebas dari kekurangan. Kepuasan nasabah juga merupakan tingkat kepuasan seseorang telah membandingkan kinerja produk yang ia rasakan dengan harapannya. Pengertian lain dari kepuasan adalah perasaan senang atau kecewa seseorang yang berasal dari perbandingan kesannya terhadap kinerja atau hasil produk dan harapan-harapannya. 
Persaingan yang semakin ketat, dimana semakin banyak produsen yang terlibat dalam pemenuhan kebutuhan dan keinginan konsumen, menyebabkan setiap perusahaan harus menempatkan kepuasan nasabah sebagai tujuan utama. Pada dasarnya tujuan utama suatu bisnis adalah untuk menciptakan nasabah yang merasa puas. Seseorang konsumen akan membuat penilaian atas suatu produk atau jasa yang ditawarkan oleh perusahaan dan kemudian ia mengambil keputusan untuk membeli yang juga didasarkan pada harapan konsumen terhadap kinerja produk atau jasa tersebut. Bila kinerja produk tidak sesuai dengan harapan konsumen. Maka konsumen akan merasa tidak puas, akan tetapi jika kinerja produk melampaui harapan konsumen maka konsumen amat puas atau bergairah. Kepuasan nasabah sangat tergantung pada persepsi dan ekspektasi mereka terhadap produk dan kualitas yang dipersepsikan oleh produsen atau pemilik jasa.

\section{a. Faktor-faktor Yang Mempengaruhi Kepuasan Nasabah}

Menurut Ratnasari dan Aksa (2011:117) untuk menentukan tingkat kepuasan nasabah ada lima faktor yang harus diperhatikan oleh perusahaan sebagai berikut:

1. Kualitas produk, nasabah akan merasa puas bila hasil evaluasi mereka menunjukkan bahwa yang mereka gunakan berkualitas.

2. Kualitas pelayanan, pada industri jasa adalah mutlak bahwa nasabah akan merasa puas bila mereka mendapatkan pelayanan yang baik. 
3. Emosional, nasabah akan merasa bangga dan mendapatkan keyakinan bahwa orang lain akan kagum terhadap dia bila menggunakan produk dengan merek tertentu, sehingga membuatnya mengalami tingkat kepuasan yang lebih tinggi.

4. Harga, produk yang mempunyai kualitas yang sama dengan produk lain, tetapi ditetapkan pada harga yang lebih murah akan nilai yang lebih tinggi kepada nasabahnya.

5. Biaya, nasabah tidak perlu mengeluarkan biaya tambahan atau tidak perlu membuang waktu untuk mendapatkan suatu produk atau jasa (pengorbanannya semakin kecil), cenderung puas terhadap produk atau jasa ini.

b. Indikator Kepuasan Nasabah

Kepuasan nasabah merupakan konsekuensi dari perbandingan yang dilakukan oleh pelanggan yang membandingkan antara tingkat dari manfaat yang dirasakan terhadap manfaat yang diharapkan oleh nasabah. Adapun indikator kepuasan nasabah (Irawan,2008), yaitu :

1. Perasaan puas ( dalam arti puas dengan produk dan jasa )

Yaitu ungkapan perasaan puas atau tidak puas dari nasabah saat menerima pelayanan yang baik dan produk yang berkualitas dari perusahaan.

2. Selalu membeli produk 
Yaitu nasaba akan puas dan akan tetap memakai dan terus membeli suatu produk apabila tercapainya harapan yang mereka inginkan.

3. Akan merekomendasikan kepada orang lain

Yaitu nasabah yang merasa puas setelah memakai suatu produk atau jasa akan menceritakannya kepada orang lain.

4. Terpenuhinya harapan nasabah setelah membeli produk

Yaitu sesuai atau tidaknya kualitas suatu produk atau jasa pasca pembelian suatu produk dengan harapan yang diinginkan pelanggan.

5. Nasabah yang loyal

Yaitu nasabah yang setia dan hanya menempati satu perusahaan sebagai mitra dalam melakukan transaksi keuangan.

\section{c. Metode Pengukuran Kepuasan Nasabah}

Menurut Kotler (1994) dalam Nasution (2005):66), mengidentifikasi 4 metode untuk mengukur kepuasan nasabah yaitu :

1) Sistem Keluhan dan Usulan

Yakni banyak perusahaan yang membuka kotak saran dan menerima keluhan yang dialami oleh nasabah, selain customer hotline dan telepon bebas pulsa juga merupakan salah satu bentuk antisipasi perusahaan terhadap kualitas produk serta kepuasan nasabah.

2) Konsumen samaran 
Yakni perusahaan mempekerjakan beberapa orang untuk berperan atau bersikap sebagai pembeli petensial ke perusahaan lain ke perusahaan sendiri. Pembeli itu melaporkan keunggulan dan kelemahan yang ada pada produknya.

3) Survey kepuasan pelanggan

Umumnya sebagian besar penelitian mengenai kepuasan pelanggan menggunakan metode survey, baik via pos, telepon, e-mail, maupun wawancara langsung. Melalui survey, perusahaan akan memperoleh tanggapan dan umpan balik langsung dari pelanggan dan juga memberikan sinyal positif bahwa perusahaan menaruh perhatian terhadap mereka.

4) Analisis pelanggan yang lari

Yakni menghubungi pelanggan yang telah berhenti membeli atau yang telah beralih pemasok agar dapat memahami mengapa hal itu terjadi supaya dalam mengambil kebijakan perbaikan/penyempurnaan selanjutnya.

\section{d. Aspek Kepuasan Nasabah}

Menurut supranto (1997) dikutip oleh amalina (2010) aspek-aspek kepuasan konsumen itu ada 5, yaitu :

1) Ketanggapan pelayanan ( responsiviness of service )

2) Kecepatan transaksi ( sped of transaction )

3) Keberadaan pelayanan ( availability of service ) 
4) Profesional ( profesionalisme )

5) Kepuasan menyeluruh dengan jasa atau pelayanan ( over all saristaction with service )

\section{Penelitian Terdahulu}

Penelitian tentang strategi pemasaran terhadap kepuasan nasabah yang dilakukan oleh peneliti sebelumnya, antara lain:

a. Saputri B (2018), Strategi pemasaran terhadap kepuasan nasabah PT. Bank Rakyat Indonesia (Persero), Tbk. Unit Batua Raya. Implikasi dari penelitian ini adalah Karena hanya variabel tempat, promosi dan karyawan yang berpengaruh terhadap kepuasan nasabah pada PT. Bank Rakyat Indonesia (Persero), Tbk. Unit Batua Raya. Hal ini perlu diperhatikan namun tidak melupakan variabel-variabel yang tidak berpengaruh signifikan terhadap kepuasan nasabah pada PT. Bank Rakyat Indonesia (Persero), Tbk. Unit Batua Raya. Untuk PT. Bank Rakyat Indonesia (Persero), Tbk. Unit Batua Raya hendaknya lebih berinovatif lagi, dalam hal ini pengembangan atribut produknya serta dapat mempertahankan dan meningkatkan penjualan dalam persaingan yang ada maka pemasaran harus dapat mengikuti perubahan pasar. 
b. Kholifah (2015), Pengaruh strategi bauran pemasaran terhadap kepuasan nasabah BMT Amal Mulia Suruh Kabupaten Semaran Hasil penelitian menunjukkan bahwa kualitas pelayanan yang terdiri atas Product(X1), price (X2), Place (X3),Promotion (X4), People (X5), Physical Evidance(X6), dan Process (X7), secara bersama-sama memiliki pengaruh yang positif. Di mana persamaan regresi sebesar $Y=0,007+0,424 X I+0,077 X 2+0,118 X 3+0,305 X 4$ $+0,038 \times 5+0,0105 \times 6+0,290 \times 7$. Selain itu, dengan uji $F$ dilihat bahwa bauran pemasaran memiliki pengaruh yang signifikan terhadap kepuasan nasabah dengan tingkat signifikansi sebesar 0,000 atau $0 \%$. Namun berdasarkan uji parsial (t), ada variabel yang memiliki pengaruh yang signifikan terhadap kepuasan nasabah yaitu dengan tingkat signifikan untuk product sebesar 0,001, promotion sebesar 0,014 , process sebesar 0,015 , dan beberapa variabel tidak memiliki pangaruh yang signifikan yaitu dengan tingkat signifikan variabel price sebesar 0,485 , place sebesar 0,244 , people sebesar 0,782 , dan physical evidence sebesar 0,504. Karena hanya variabel produk, promosi, dan proses yang berpengaruh terhadap kepuasan nasabah BMT Amal Mulia, hal ini diperhatikan lagi namun tidak melupakan variabel-variabel lainnya yang tidak signifikan terhadap kepuasan nasabah BMT Amal Mulia. Untuk BMT hendaknya lebih berinovatif lagi dalam menerapkan strategi pemasaran, dalam hal ini pengembangan atribut produknya serta memperluasa lagi promosi tentang BMT kepada masyarakat, dan mempertahankan atau meningkatkan penjualan produk dalam persaingan pasar sasaran. 
c. Roisah, Iskandar (2013). Rancangan yang digunakan dalam penelitian ini adalah metode deskriptif verifikatif. Analisis data yang menggunakan regresi linear, uji koefisien, determinasi dan uji t. berdasarkan temuan dan hasil uji-t (parsial) terdapat pengaruh positif yang signifikan terhadap kepuasan nasabah. Sedangkan kontribusi strategi pemasaran kepuasan nasabah ditunjukkan oleh koefisien determinasi tersebut dijelaskan sebesar 0,472 , artinya strategi pemasaran berpengaruh terhadap kepuasan nasabah $47,2 \%$ sedangkan sisanya $52,8 \%$ dipengaruhi oleh variabel yang tidak diteliti. Dan hasil penelitian menunjukkan $R=0,687$ hampir mendekati 1 yang berarti variabel strategi pemasaran mempengaruhi kepuasan nasabah.

\section{B. KERANGKA PIKIR}

Kerangka Pikir

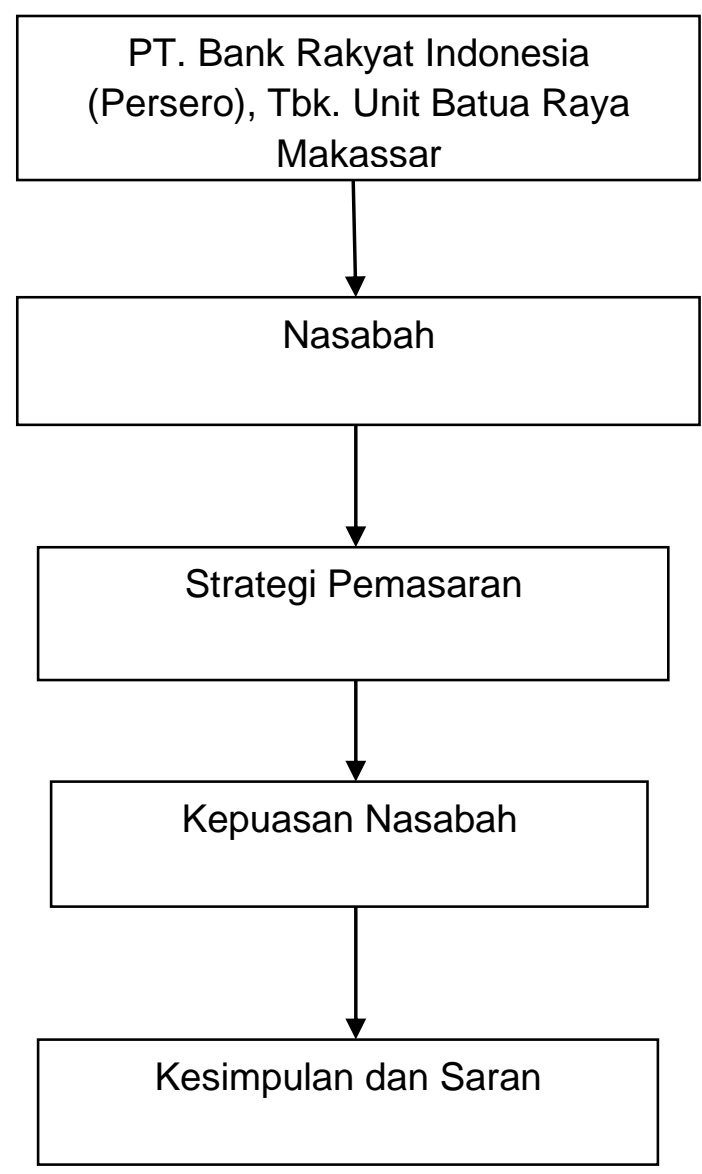




\section{Keterangan :}

PT. Bank Rakyat Indonesia (Persero), Tbk. Unit Batua Raya. Dalam rangka meningkatkan kepuasan nasabah yaitu dengan melaksanakan strategi pemasaran menganalisa mengenai variabel produk (product) PT. Bank Rakyat Indonesia (Persero), Tbk. Unit Batua Raya Makassar dan physical evidence (bukti fisik) yang mempengaruhi kepuasan nasabah PT. Bank Rakyat Indonesia (Persero), Tbk. Unit Batua Raya Makassar. Hasil penelitian ini diharapkan memperoleh kesimpulan dan saran sehingga memberikan masukan dan informasi bagi PT. Bank Rakyat Indonesia (Persero), Tbk. Unit Batua Raya Makassar dalam pengambilan keputusan.

\section{METODE PENELITIAN}

\section{A. LOKASI DAN WAKTU PENELITIAN}

Dalam penyusunan penelitian ini, penulis melakukan penelitian pada PT. Bank Rakyat Indonesia (Persero), Tbk. Unit Batua Raya yang berlokasi di Jl. Batua Raya. Adapun waktu yang digunakan selama 1 (satu) bulan.

\section{B. JENIS DAN SUMBER DATA}

a. Jenis Data

Data yang bersifat kuantitatif, yaitu data yang diperoleh dari perusahaan berupa angkat-angka atau besaran tertentu yang bersifat pasti.

b. Sumber Data 


\section{Data Primer}

Data primer merupakan data penelitian yang diperoleh secara langsung dari sumber asli. Data primer yang digunakan dalam penelitian ini adalah hasil pengisian kuesioner oleh nasabah pengguna tabungan BRI BRITAMA pada PT. Bank Rakyat Indonesia (Persero), Tbk. Unit Batua Raya Makassar.

\section{A. TEKNIK PENGUMPULAN DATA}

Metode pengumpulan data yang digunakan dalam penelitian ini adalah Kuesioner. Kuesioner merupakan serangkaian atau daftar pertanyaan yang disusun secara sistematis, kemudian dikirim untuk di isi oleh responden, (Bungi,2005:123), sedangkan menurut Arikunto (1997:128) angket atau kuesioner adalah sejumlah pertanyaan tertulis yang digunakan untuk memperoleh informasi dari responden. Skala dasar pengukuran Likert (Sugiyono,2010) memakai urutan yaitu:
a. Sangat Setuju (SS) $=5$
b. Setuju (S) $=4$
c. Cukup Setuju (CS) $=3$
d. Tidak Setuju (TS) $=2$
e. Sangat Tidak Setuju (STS) $=1$

\section{POPULASI DAN SAMPEL}




\section{Populasi}

Keseluruhan dari unit analisis yang diperoleh berdasarkan analisis ciri-ciri yang di duga dari sampel yang hendak digeneralisasikan atas analisis secara umum. Target populasi dari penelitian ini adalah seluruh nasabah tabungan BRI BRITAMA PT.Bank Rakyat Indonesia (Persero), Tbk. Unit Batua Raya sebanyak 2.425 nasabah.

2. Sampel

Bagian dari jumlah dan karakteristik yang dimiliki oleh populasi tersebut dengan menggunakan Purposive Sampling untuk menentukan sampel penelitian dengan beberapa pertimbangan yang bertujuan agar data yang diperoleh nantinya bisa lebih representative.

\section{E. DEFINISI OPERASIONAL VARIABEL}

Seseorang akan mengetahui pengukuran dengan membaca definisi operasional dalam suatu penelitian, sehingga dia dapat mengetahui baik buruknya pengukuran tersebut. Untuk lebih jelasnya berikut ini peneliti mendefinisikan operasional variabel sebagai berikut:

1. Strategi Pemasaran $(X)$

a. Variabel Product 
Adalah sesuatu yang dapat ditawarkan dipasaran untuk memenuhi keinginan dan kebutuhan nasabah. Indikator product : memiliki keunggulan, ciri khas, dan menarik

\section{F. ANALISIS DATA}

1. Uji Instrumen

a. Uji validitas

Uji validitas digunakan untuk mengukur sah atau valid tidak suatu kuesioner. Alat ukur yang digunakan dalam pengujian validitas adalah daftar pertanyaan yang telah diisi oleh responden dan akan di uji hasilnya guna menunjukkan valid tidaknya suatu data. Bila valid ketetapan pengukuran data akan semakin tetap alat ukur tersebut. Dikatakan valid jika nilai signifikan $\leq 0,05$.

b. Uji Realibilitas

Menurut Sugiyono (2012:119) uji realibilitas digunakan untuk mengetahui keandalan kuesioner yang digunakan.Reliabilitas adalah indeks yang menunjukkan sejauh mana alat ukur dapat dipercaya atau diandalkan. Dikatakan reabil jika nilai Cronbach Alpa $\geq 0,60$. 


\section{DAFTAR PUSTAKA}

Ernawati. 2006. Pengaruh Bauran Pemasaran Terhadap Keputusan Nasabah Untuk Memilih Tabungan Ummat di Bank Muamalat Indonesia, Cabang Medan. Tesis.Universitas Sumatera Utara Medan.

Irawan, Handi. 2008. Membeda Startegi Kepuasan Pelanggan, Cetakan Pertama. Jakarta : PT Gramedia.

Kholifah, Nur. 2015. Pengaruh Strategi BauranPemasaran Terhadap Kepuasan Nasabah BMT Amal Mulia Suruh Kabupaten Semarang.Skripsi S1 Jurusan Syariah Dan Ekonomi Islam Sekolah Tinggi Agama Islam Negeri Salatiga.

Roisah, Riris, and lis Iskandar, 2013.Pengaruh Strategi Pemasaran Terhadap Kepuasan Nasabah Pada PT. Bank Tabungan Negara Kcp Kopo.Jurusan Manajemen Fakultas Ekonomi BSI

Saputri, B Ria, 2018. Strategi Pemasaran Terhadap Kepuasan Nasabah PT. Bank Rakyat Indonesia (Persero), Tbk. Unit Batua Raya. Skripsi S1 Jurusan Manajemen Dakwah, Fakultas Dakwah Dan Komunikasi UIN Alauddin Makassar

Selviana, 2020.Pengaruh Komunikasi Pemasaran Terpadu Terhadap Kepuasan Nasabah Pada PT. Bank Mandiri (Persero), Tbk. Cabang Makassar Daya.Skripsi S1 Jurusan Manajemen. 
Supranto, J. 1997. Pengukuran Tingkat Kepuasan Pelanggan. Jakarta : Rineka Ipta

Tjiptono, Fandy. 2005. Strategi Pemasaran 1, Edisi II. Yogyakarta : Andi Offset.

Zulaikha, Ikha, 2011. Analisis Strategi Pemasaran Pada PT. Bank Rakyat Indonesia (Persero), Tbk. Cabang Takalar.Skripsi S1 Jurusan Manajemen Fakultas Ekonomi Universitas Hasanuddin. 